\title{
THEORIZING SMALL TOWNS IN ANTHROPOLOGICAL VIEWS IN NEPAL
}

\author{
Badri Nath Bhatta*
}

\begin{abstract}
This paper has attempted to define the terms urban, urbanism, cities and towns which are confusing terms however interrelated. An interdisciplinary approach has been adopted to achieve this objective. The towns are small in size, population along with development basis than cities. Earlier stage of towns or small towns was village. As a foundation, village was the original form of all. In this sense, it is focused on the overall urban-rural structure where rural/village has crucial role to develop town to cities. Archeologically, the effort to subsist in primitive people was based on the process of agricultural farming. The first and early civilization in human behaviours was found in Near East (similar as Middle East in West Asia) as initial town at the bank of the river. Therefore, the origin of the towns indicates early people began to be civilized in their daily activities. Later, the towns were extended. In Nepal, there are generally urban areas, cities, towns and villages as local levels in the forms of Metropolitan Cities, Sub Metropolitan Cities, Municipality, and Rural Municipality at the one side, DUDBC at the other has classified into five classes- metro city, sub- metro city, city, sub-city or small town and urban centre based on urban faculties and population.
\end{abstract}

Key words: Urban, town, metropolitan, municipality, democracy, archaeology.

\section{INTRODUCTION AND OBJECTIVE}

Conventionally anthropology studied traditional and primitive people and their cultures as 'infinitive curiosities'. Further it mainly focused to study the "others" or "other-wises" of Asia, Africa and other Third World countries during colonial period in the world. Now, its study areas have been extended from rural to urban, from own (native) to other and from developed to developing societies. Ember, Ember \& peregrine(2002) say that with the help of archaeologists (who study of human artifacts and material remains) and paleoanthropologists (as sub branch, who interpret

* Mr. Bhatta is a Lecturer, Padmakanya Campus, Baghbazar, Kathmandu, and currently PhD Scholar, TU. 
all the clues left by early ancestors), pre- historic materials and evidences including ancient cities and towns were studied in anthropology. Rua \& Torres (2016) state prior 1940; anthropologists thought urban studies are delimited within scope of sociology. Then, they began to study adaptive behaviours, cultural patterns, ethnic and racial tensions of urban poor beginning from Chicago school. It is said that main characteristic of anthropology as modern discipline is to develop different sub- branches in required basis to address the issues as relevant in its subfields. As a result, urban anthropology has been developed as sub-discipline and focused to study the urban issue/concerns related to people's practices and cultures. They define "Urban anthropology investigates cities and the socio-cultural experiences and practices of urban dwellers in relation to the larger socioeconomic and cultural contexts".

In dictionary meaning, towns are developed from rural background or folk life and they are the centres of population larger than village and smaller than city. In this sense, town is the semi-urban area developing towards city from village or country. Town is developed from township and township can be advanced from village (Xiaoyi, 1993; Southall, 1993) as "folk-urban continuum" based on the view of Robert Redfield, 1939 cited by Marshall (1994, p 555). Some says towns as semi/mini- urban area, some others say as sub-city and others say they are developed from the rural setting. In metro city, the concept of town planning has been extending in some urban areas when some model programs representing from advanced urban characteristics are planned and implemented. In Kathmandu, we can observe some such mini urban plans as Nayabazaar (Khusibu) Land Pooling Project, Gangobu (Samkhusi) House Improvement Area as Town Planning and so forth as sample programs to motivate/ transfer the views of new modern trends to urban people. As discussed above, anthropology began a concern over urban study from 1940. Therefore, this discipline regarding to urban issues is in infantile stage comparing to sociology, however anthropology has historical roots with urban sociology. In this context, we can link urban anthropology with Chicago School or Chicago urban sociology especially led by Robert Park and Ernest Burgess to motive the students in fieldworks and empirical study firstly in 1920s. Later urban anthropology was also flourished there. The next important theme of Chicago University concerned with the study of the city. They administrated survey and some qualitative methods to study the urban problems in North America where various types of delinquencies, crimes and other problems 
made critical to societies due to the causes of immigration (Marshall, 1994). Gradually then urban anthropologists began to conduct the study regarding urban issues especially urban poverty, practices and life styles of urban people. Seymour-Smith (1986) says as anthropology of the city, urban anthropology studies on the comparative views between rural and urban centres, inter-ethnic relations and migration trends, socio-cultural conditions of excluded and marginalized people and so forth. To him, distinctive social psychological characteristic as the view of Durkheim on Division and Labours in Society (1893) is found in city and towns. This view influenced both Chicago school of urban anthropology and folk-urban continuum (continuity) of Redfield, 1930 (both of them are mostly claimed as sociologists). He argued transformation will be effective from folk to village and from town to city.

Bhandari (2010) clearly reflects his view that urban anthropology concerns with the detail and systematic study of cultural systems of the day to day people's life in urban centres by using basically ethnographic method. As a result I argue that anthropology has also concerned with urban problems in cities and towns with it sub-discipline. It is reality that anthropological literatures on town and urban areas are few. Further, it is nominal in Nepal. Interdisciplinary approach in this context is useful to analyze such issue. Sharma (2003) from geographical background preferring to economic aspect, defines the concept of urbanization in general consensus viewi.e. "structural shift in employment from agriculture to non-agriculture pursuits" (p.375). Theorizing town is not an easy; this paper has tried to touch the historical roots in this given concepts and theoretical links of the towns in modern social sciences especially anthropology and some views from geography and relate them practically in Nepali context. By showing the prospects and problems in this path. This paper concludes by saying town has important role to develop rural-urban interface as the views of Seymour-Smith (1986) and urban -rural linkage of Adhikari (2005) and Pradhan (2003). Pradhan further states, "Urban rural linkage includes three major aspects - urban centres and their structure and function and spatial distribution, resources-use system of the rural /hinterland areas, and services and institutions that facilitate linkage between urban and rural areas" (p.3).

\section{REVIEW OF LITERATURE}


As Subedi (2014), the terms urban, urbanism, cities and towns make sometime confusion and they are closely related each other. Sometime some terms like sub -urban, under urban and others are also used. The term urban indicates the changes from the rural to be advanced whereas urbanism deals with the pattern of social life in advanced areas. Both termsurbanism and urbanization denote the predominance and growth of urban centres in society (Seymour-Smith, 1986). Moreover the term urbanization in simple sense is the extension of formulating the city. In boarder sense it is the process of modern development as industrialization based on the views of Sharma 2003; Subedi, 2014 and Shrestha, 1991. They especially emphasize on non-agricultural sectors- trade, industries etc as economic development of Shrestha (1991) based on geographical and economic perspectives. Subedi (2014) introduces urban, urbanism and urbanization and concludes that urbanism has embeddeddness with the complexities - non-agriculture, commercial and so called modern ways of life while ruralism with simplicities- agrarian, subsistence and traditional ways of life (p. 97).

In Dictionary of Sociology, Marshall (1994) argues that controversial views are found about the origin of urbanization whether it is developed from 'the decline of feudal or the growth of capitalism'. Mostly the process is related to large scale changes in modern society. He then said that the term 'under-urbanization' is often used in former socialist countries due to not matching between industrial production and sufficient houses and urban infrastructures while 'over-urbanization' is applied in Third World cities' being larger population than economy. Marshall concludes that the urban societies in wider sense have main two characteristics- advanced industrial economy and modernized social structures. More or less, the meanings among different perspectives are similar. In this sense, the study areas of this subfield are cities, town to township including shanty towns (slum and squatter settlements in the most urban centres of Third World countries due to influx of migration from folk life).

Adhikari (2005) has used the terms- town/urban centre alternatively and argues 'towns are importance to promote rural/regional development' through rural - urban linkages as Pradhan (2003). However it is found that urban centres are earlier stage than the town. Hence, it is clear by saying between town and city- towns are small in size and population than cities and urban may be the town or city based on size and population changing advanced status from rural situations at all. Pradhan further argues that 
urban centre may refer to village or market centre, town or city to provide services (p.3). They all are in total as urban centre to provide different goods, services as exchange including job and at the same time they are local administrative unit/ body covering urban settings mainly. Hence, market centres is the focal point for economic, social and administrative activities to the surrounding areas (Sharma, 2003). In nutshell, it is expected that such types of system strengthen modern democracy- decentralization, change/ transformation and participatory process in grassroots levels. Based on the Federal Republic System in Nepal, the local levels are not divided on the basis of the concepts of city and towns though both terms are used during general discussion earlier as required.

As stated above, we can conclude that urbanization is in simple sense, the process for the formation of city. In broader sense, urbanization as industrialization is the indicator of modernization shifting from agriculture pursuit in the context of development fields. Seymour-Smith (1986) states the meaning of town within bracket in the concept of city. And he says the town comparing to city has distinguished by "the arbitrary or random criteria of size" while city is "the product of increasing role specialization and centralization of social institution". Therefore he argues that city has special environment than town by the integration of multiple factors- social, political and economic in a specific region. He also argues that the city itself is paradoxical- it concerns mainly with ecological or demographical and economic or political aspects of urban areas.

\section{Genesis of the Ancient to Modern Urban Process}

The ancient records and evidences could not be studied by historians. So archaeologists can study the evidences before the advent of writing. As we know the time before the development of writing is recognized as pre-history. Archaeologically therefore we can relate the terms-towns and cities from prehistoric, then historically from ancient to modern phases in the world in general and then focusing to Nepal in particular. After the process of early human evolution, most of the paleoanthropologists agreed that the early human beings were Homo erectus, first tool maker though Australopithecus was also said. But from the time of Neanderthal, they began to live at first in the cave, rock shelter and other secured areas. It is remembered that the cave shelter cannot be immediately shifted into urban status. It took thousand years. Gradually human settlements openly set up in useful places. Such types of settlements in pre- historic period occupied 
near the bank of rivers for the safety and irrigation to agricultural crops and certainly they were based on rural background. Therefore, it is said that traditional farming cannot be the feature of urban status as SeymourSmith (1986), Shrestha (1991) and Sharma, 2003). The rural settlements continued up to about 6000 B.C.E (Before Common Era while B.C, Before Christ).

Then new civilizations were seen as different facilities or infrastructures- writing, cities/towns, monuments, craft specialization and so forth in and around Near East (popular at present as Middle East in West Asia). Such types of civilizations later transferred in northern China around 1750 B.C and in northwestern India after 2500 B.C in Old World though Scupin \& Decorse, 2012 argue that it was 4500 years ago when their book was published. They were also found in Mexico and Peru as New World countries and other areas (Ember, Ember \& Pregrine., 2002 and Pradhan, 2003). In reality, these types of civilizations were ancient urban areas and cannot be classified them into city or town. Consequently, new ancient characteristics- few differences in wealth, power and status in the human behaviours from one to other communities was realized as civilized status directing to early urban development. Archaeologists generally assume that inequality in the death especially burial process indicates the advent of inequality in overall human life. Therefore, the origin of the early urban life as towns indicates early people began to be civilized in their day to day lives/activities based on inequality.

With the help of archaeological evidences, we can discuss on early human civilizations - Mesopotamia, Egyptian, Greek and Roman to Indus and Chinese to embed the origin of early urban settings in the form of cities, town to townships as above. Firstly it is known that the term 'civilization' is close to the 'city'. The first civilization originated in the valley of the Tigris and Euphrates rivers in a part of the Middle East called as Mesopotamia. In South Asia, the Indus civilization was developed in and around the Indus River in 2500 B.C.E ((Ember, Ember \& Pregrine., 2002 and Pradhan, 2003, p. 19). This period is still paradoxical and some say the main period of this civilization was between 2600 to 1900 B.C.E extending Indus to Afghanistan and Iran. Among the different urban areas of this ancient civilization, Harappa and Mohendo Daro were the famous places. Among them, the last one was very big and popular where about 35,000 populations may have. This civilization has the contribution to initiate and develop some early alphabet and Indus script, multi-rooms houses, 
bathing pools and artistic forms. Such types of ancient civilizations later were mysteriously collapsed and it is assumed there was still missing link between ancient and medieval cities and towns (Scupin \& Decorse, 2012). As a result of this civilization in this area, the urban centres as city and town gradually developed in different parts of India and then in Nepal.

Ray, (2017) has made some efforts for highlighting medieval Indian cities and towns. In south Asia, the popular Indus civilization was wonderfully collapsed as stated above and such type of civilization was continued for 800 years up to $1700 \mathrm{BCE}$ later. Hence, there is a missing link between ancient civilization and then urban process in South Asia. He argues that urban study in India was very limited. The study in Indian towns at first began by western scholars. Ray adds that as Max Weber, other scholars said the medieval towns were only military outposts. Then, in 1915 Patrick Cedes as sociologist at Bombay University began working at urban areas and some geographers and historians were involved later. In between $300 \mathrm{BC}$ to $600 \mathrm{AD}$, Ray argues that some Indian towns were developed and declined. In 1200 AD, the Guptas rulers raised some towns and again declined and similarly some new towns began in 18th century in India and they connected with East India Company as British colonial power to involve in trades and control overall India. In modern period, urbanization is the global phenomena and it is perceived an indicator of modern development. Around 50 percent populations in the world live in the urban areas from city to towns. Due to the rural to urban migration trend rapidly, city and town are growing day to day. It is also estimated that the growth rate has been increased more in developing than developed countries where the urban population is estimated to be double, i.e. from 2.6 billion in 2010 to 5.2 billion in 2050. India and China's urban growth rate at 29 percent and 53.3 percent respectively (Devkota, 2012).

In modern India, Mallick (1981) states the concept of urbanization in Indian context and says that urbanization and technological transformation are the two major processes that indicate the symbol of economic development. Since 1901, India has begun to define town in its census. It may be possible with the influence of British colony. The term town is defined, based on 1901 census of India with different features as - i) every municipality of whatever size; ii) all civil lines not included within municipal limits; iii) every other continues collection of houses, permanently inhabited by not less than 5000 population as the decision of provincial superintendent. Sharma (2003), Subedi (2014) and K.C (1998) 
state that the data on urbanization in Nepal have been recorded since the 1952/54 census and additionally Sharma (2003) adds some 10 "prominent" settlements in this process were there (p.376). At the beginning, they say that the urbanization process was slow. Subedi (2014, p 95) states that 27 percent of Nepal population covering 130 designed urban areas/ municipalities in 2014 but growth rate was 8 percent ( 6 times higher than national population) as Sharma (2003)'s view triple in 2016. Therefore, the present growth rate has been increased, however, desired changes in this sector is urgent considering the present urban issues.

In Nepal, the pre-historic sites in Kathmandu (Dumbarahi, Bagmati etc.), Muktinath, Tinau River near Khaseuli, Dang and others were also famous. After drain out in Kathmandu, different dynasties (Gopala, Mahishpal to Kirat) ruled over there where the first king was Dhamakar and the ruling centres of the different rulers were Isumati (Tukucha), Gokarna, Matatirth and Sankhamul etc as ancient towns. The oldest cities or towns were in ancient Kathmandu valley (Kasthmandap, Bhadgau and so on) and Lumbini. The first ancient coins as Managka issued at the time of Mandev indicates the commercial transaction and exchange certainly happening in ancient urban areas (Pandey \& Regmi, 2005 V.S). Likewise, the ancient civilizations were also in Janakpur, Biratnagar and some other places of Nepal based on legendary explanations. Devkota (2012) remarks the ancient and medieval history of Nepal also highlighted the trade route between Nepal, India and Tibet and silk route also which were flourished for trading from place to place by developing then cities and towns. Simraunagad was older famous state during the period of King Jayasthiti Malla close to Indian borderline where it is assumed certainly some cities were also developed. During ancient to medieval periods, Dolakha, Nuwakot, Banepa, Panuti, Banglung, Jumla, Dullu Dailekh and other areas of Nepal were known as urban centres. After unification of Nepal, other urban areas were developed in Bandipur, Pokhara, Tansen, Khasauli. In 1952/54, 83 percent urban populations were in only in Kathmandu but later this figure declined due to the emergence of urbanization processes in other hill plains and Tarai areas because it is the continuous process from past to present and in the future also (Devkota, 2012; Subedi, 2014 and Sharma, 2003 ).

In the past, the growth rate of urban residents was very limited in Nepal. At the end of Rana autocratic system in 1951, there were very few cities and towns in Nepal such as Dharan, Biratnagar, Dolakha, Banepa, Kathmandu, Thori, Narayanghat, Bandipur, Pokhara, Palpa, Khaseuli, 
Baglung and so on. After the eradication of Malaria from Tarai, construction of east- west highway, expecting opportunities and facilities etc, hill people began to settle down in Tarai and urban areas though there were a few towns Panchayat at local levels in some emerging and developed urban cities during Panchayat period. As the result of enormous pressure of population from rural to urban, especially in Kathmandu Valley (all three cities) have faced several challenges to maintain their infrastructures, employments, sanitation properly. Due to the over migration, the pressure of slum was rapid outside and inside the ring-road. Likewise, public transport was/is overcrowded, the water supply system was/is fragile and so forth (K.C, 1998, p. 5) but he did not make clear the concept of slum and relating with squatter. He further argued that the reasons for rural - urban migration was mentioned in the census, 1981 but not recorded in 1991 (p.26). K.C adds that nearly 65\% populations of 1981 recorded the reasons about such trend on urban areas and the rest were silence. They are services in urban areas, trade and commerce, study and trainings etc. The reasons vary from town to town. In Kathmandu, a service is the major reason followed by trade and commerce.

In 1991, urban population was 10 percent and 13 percent in 2001. Up to 2011, 17 percent populations were in urban areas where the urban growth rate was 3.38 percent (Devkota, 2012). KC (1998), Subedi (2014) and Sharma (2003) state similar views. They say 1961 census defined Sahar (urban areas) as having a minimum population of 5,000 and included 16 such localities (based on location of schools, colleges, government offices, legal court, and market facilities) with a total population 336,622 (3.6\%). Further Sharma states an urban area in 1962 is interpreted in Nepal not only as a settlement but also as unit of local government as stated MoFALD, 2074 BS. More urban populations in Nepal are concentrated in Tarai especially eastern and central Tarai. Similarly they are grown in mountain and hills mid and far west, however they are not well developed as urban style economic transformation especially non- agricultural sectors (Shrestha, 1991 and Subedi, 2014). To sum up, the real urban networks in Nepal was found in quadrangle/rectangle shaped in central section- i.e. Kathmandu, Pokhara, Butwal and Hetauda (Shrestha 1991; K. C, 1998 and Sharma, 2003). At present, municipalities have covered overall parts of the country except some mountain areas when Government of Nepal has declared new municipalities based on federal republic system of the total 753 local levels, 293 are municipalities including metro and sub metropolitan cities (MoFALD, 2017). The growth rate of urban areas is certainly increased. 


\section{DISCUSSION}

As we discussed earlier on city and towns, the phrase of small town now is popular elsewhere. As discussed earlier, small towns are a key link point in the overall urban - rural structure because they are developed from village or country and they help to shift into town or city to metro city whatever intended. Seymour-Smith (1986) states the town comparing to city has distinguished which has no special criteria as arbitrary. Archeologically, it is argued that when primitive people began the process of agricultural farming for subsistence, they initiated to stay at small village. Gradually, some characteristics of the early civilization in human behaviours in different parts of Old to New World were emerged (Ember, Ember \& Pregrine, 2002). In modern period, different types of studies in various countries are reviewed and stated as follows:

The concepts of cities, towns to small towns can be found studying in USA, China to other countries based on anthropology. Xiaoyi (1993) says small town in China are more important because they promote the process of urbanization and industrialization. Anthropological study of urban areas - city and town in China has been recently beginning and it is gradually extending. He defines "Small towns are a key link in the overall urbanrural structure". For the clarification of the term of town, town is developed from township and township can be advanced from village. Therefore, the three layers have structural relation from one to other and village is basis among the three layers as saying earlier while Local Administration of China further divides into additional two. Hence, China in contemporary administrative system has five statuses of small towns. They are provinciallevel, prefectural-level, county-level, township-level and village-level, from higher to lower order respectively. As view of Xiaoyi (1993) in China, Southall has analyzed American small towns with similar as earlier three layers of China. They are town, township and village however the writer argues that American culture makes them in comparison with other parts of the world impossible. As discussed earlier (see p. 66), USA has important contribution to carry out urban study led by Chicago schools and then other universities and developed urban anthropology. As Chinese efforts, anthropologists from Australia have studied small towns and other urban areas since 1970s and 80s. Based on changing structure and functions of small towns, they began community study for sustainable small town (Courvisanos \& Martin, 2017). India began such study from sociological view in Bombay University in 1915. Nepal is just crawling in this path. 
Pradhan (2003, p. vii) saying central theme of his book and argued 'the development to rural areas in developing countries is itself not a complete answer but it requires together the development of small towns as effective measure. He relates small town with rural development in Nepali context'. We can also relate the study of cities in Nepal based on interdisciplinary approach including anthropology.

Recently Elinoff, Sure \& Yeoh, (2017) have studied on the 'Construction of Asia' focusing to some famous Asia cities (from Mumbai to Singapore, Beijing to Phnom Penh) based on urban study, anthropology and geography. They argue Asia is fertile land for the construction in the process of urbanization. They remark that labours, company, materials and capital are required for the construction of cities /buildings. The construction site is critical because national to international economic, political and social processes everywhere play vital role. In study, they analyze their views focusing on 3 variables-- construction materials, construction economy and construction politics and conclude that urban economic, politics and space can influence for constructing cities and towns.

In Nepalese context, Thapa (2016) argues that Nagar Vikas Samiti was organized to systematize urban development in the country. In doing so, an Act in the name of Nagar Vikas Kanun was formulated. Based on this Act, later some cities like Dhankuta, Pokhara and Surkhet were declared as regional development centres. Gradually this Law/ Act was developed on the basis of decentralization policy. For overall administration and management of urban areas in the names of cities or towns, Urban Development Authority has to be set up as governmental agency (as Department of Urban Development and Building Construction). Nepal is the nation- state recognized as federal republic country and power is allocated into local, provincial and federal levels, however he argues that the present constitution is silence on urban development policy or plan. Most of the Laws and Acts based on new structure are under formulation process. In future, it is expected that a clear policy addressing urban development will be declared. Different Acts and Regulations such as Town Development Act, 1988, Local Self Governance Act 1999 and among others were promulgated along with National Plans and Policies. Based on these acts, plans and policies, portfolio of each ministry and agency for urban areas has been made obviously. Consequently, Department of Urban Development and Building Construction (DUDBC) under Ministry of Urban Development has planned and implemented urban development plans and programs 
while Ministry of Federal Affairs and Local Development is responsible for administration and management of overall local levels in Nepal (Devkota, 2012). But MoUD does not concern on rural setting, only plans and thinks about urban development and its proper design. Therefore, the outlook to see the local levels is different from one ministry to other. As a result, local levels could not get the change as expected.

As stated in Report and Recommendations of President (RRP) for Nepal of ADB (2014), the Bank has made some supports in Small Towns Water Supply and Sanitation Sector under Department of Water Supply and Sewerage in Nepal. In this document, small town is clearly defined so that the project office could easily select the towns based on its criteria to implement the water supply program as required. Therefore, ADB states "Small towns are defined mainly as towns that have (i) a population of 5,000-40,000; (ii) minimum density of 10 people per hectare; and (iii) permanent access to roads, power, and telecommunications, i.e., potential for growth" (p.1). The authority of DUDBC claims that it has no technical base.

In the field discussion of DUDBC, the Department has recognized town as small town based on its administrative structure. Under the DUDBC's Administrative Structure, Small Town Shakha (Branch) is one of the branches of Urban Development Mahashakha (Main Branch). But the town is considered as larger or secondary towns also. In the administrative structure of Government of Nepal, DUDBC has separate Small Town Branch which makes required polices and plan in Nepal formally on small towns. We can see generally urban areas- cities, towns and villages as local levels in the forms of Metropolitan Cities, Sub Metropolitan Cities, Municipality, and Rural Municipality. They all are in total as local administrative unit/ body based on the Federal Republic System. It is expected that such types of system strengthen modern democracy in grassroots levels. MoFALD (2017) has divided local level bodies of Nepal into four forms as federal restructure:

Table 1: Numbers of Local Levels in Nepal

\begin{tabular}{|l|l|l|}
\hline Local Levels & Total Numbers & \% \\
\hline Metropolitan Cities & 6 & 0.7 \\
\hline Sub- Metropolitan Cities & 11 & 1.4 \\
\hline Municipalities & 276 & 36.6 \\
\hline Rural Municipality & 460 & 61.1 \\
\hline Total & $\mathbf{7 5 3}$ & $\mathbf{1 0 0}$ \\
\hline
\end{tabular}

Source: Summary Introduction of Rural Municipality and Municipality in Nepal, 2074 
The absolute majority (61\%) still was the numbers of rural levels followed by municipalities (37\%), sub metropolitan (1\%) and below 1 percent of metro city whereas nearly 39 percent local levels are urban areas based their total numbers while 27 percent urban population were in urban with growth rate 8 percent in 2014 (Subedi, 2014). Now the urban areas are highly grown in Nepal though most of the municipalities, unlikely urban feature were based on agriculture (Table 1).

To support city and towns, some other organizations and civil society were also there. Kathmandu Valley Development Authority has provided some important supports for urban infrastructures in Kathmandu valley based on KVDA Act, 1988/89. For lobbying and networking among municipalities, Municipality Association of Nepal has been organized as civil society in urban areas (Devkota, 2012). Similarly, Town Development Fund since its inception in 1987 has been providing technical and financial supports to municipalities and emerging towns in Nepal. However, the result can not be positive. The town as census, 2052/54 was defined as an area with a population of 5000 or more with urban facilities - school, college, judicial and administrative offices, market, transport and communication as earlier [Sharma, 2003; Subedi, 2014, and Shrestha (n.d)]. Later Town Panchyat Act, 1962 revised and added the number of population of 10,000 to be Nagar Panchayat (town). Shrestha (n.d) unlikely Subedi (2014) citing from CBS, 2012 adds the urban population of then 58 municipalities and 265 small towns make the figure of 30.59 percent of 26.49 million population of Nepal.

During the visit of DUDBC on December 2017, a discussion had been done with Branch Chief of Small Town Branch and other officers and studied very few reports and regular bulletins published by this Department regarding to small towns. In 2007 B.S, 132 towns were listed as small towns in the country and only 72 towns were studied. In 2010, the $1 / 2$ to 1 paged brief profiles of 83 towns were prepared (DUDBC, 2007 and 2010). However both reports are silence about the profiles of earlier or new list. This raises the question on record and updating system along with clear planning and vision on the towns in this office. DUDBC (2010) has firstly defined small towns as the 'Engine of Growth'. In anthropological literature, such type of phrase is not found, may be from economics sense. Therefore, they are to be developed in Nepal so that town can help to increase the growth rate of the production. In the report, small town has been defined as the thick/ compact human settlement which is larger than urban centres but not declared as municipality and where urban infrastructure services and 
facilities (amenities) associated with mix land use practice are available. Based on this definition, following characteristics can be prepared:

- Small town is the growth centres/service centres to provide the urban amenities to the rural areas in and around such towns,

- Practicing mixed economy ( rural and urban) but dominated by urban ones;

- People day to day life is based on urban nature;

- Mixed housing system both of business as well as residential;

- Commence of trade and profession without specialized and so on.

The Department has prepared basic urban amenities in both reports. The figure and amenities are population, education, health, sewer, road, electricity, bus-park, play ground, financial institutes and industries etc. It has again classified urban areas into five classes based on population in 2013. They are- metro city (above 300,000 with defined norms and standards), sub- metro city (100,000-300,000 with defined norms and standards), city (above 40,000 or equal to or less than 100,000 with defined norms and standards), sub- city/ small towns (above than 10,000 or equal to or less than 40,000 with defined norms and standards), and urban centre (having at least 50 shops or outlets within $100 \mathrm{~m}$ from the centre) based on its planning norms and standards ( DUDBC, 1956). The department is silence on town but only on small towns. Despite such efforts, DUDBC does not have any special plan for towns in future. Therefore, it is said new vision for small towns is urgent. Unlikely Seymour-Smith (1986)'s view on arbitrary features of town, DUDBC has developed certain criteria to be small town principally, the situation of small town related policy is arbitrary and illogical, in practice.

The study areas of modern anthropology have been growing now because different sub-branches have been emerging in this field. In other modern social sciences- economics, geography etc, different efforts have been made to study about the towns and cities. Moreover, urban anthropology as subfield can comparatively study between towns and cities, rural-urban linkage, shanty areas and other similar issues. It is also helpful to carry out the research on intra and inter ethnic relations, socio- cultural change, urban development, urban slum and squatters and their impacts in urban life etc through interdisciplinary approach. Despite the significance role of urban anthropology in the study of city and towns, most of the Nepali towns are still far behind to carry out the ethnographic study based on modern social sciences through interdisciplinary approach so that detail ethnographic profiles of the urban areas can be prepared clearly. 
Recent restructure of Nepal's local administrative levels indicates they are divided as metropolitan, sub-metropolitan, municipality and rural municipality as local levels though most of the municipalities to rural municipalities are still based on agriculture. In fact this is not the indicator of urbanization. From the country or rural level, the initial stage of urban as market or small town begins as transitional where agriculture will be effective. Comparing to metro city, urban centre or market is not comparable. However all these are urban at all. Similarly, there is still lacking to coordinate between concerned ministries to agencies about the concept and definition and their classification on town to city. Therefore, country or rural to small town and town than city found making some confusion. Hence, a clear effort in future through proper coordination is certainly essential for cutting through such jungle.

Rural to urban migration especially slums and squatter in urban areas along with problems of unplanned urban program of Nepal have played decisive role for bringing problems in urban development. Further, the situations of existing and emerging towns are critical because they are only shifted in transitional status (little progress than rural but not being still urban). Likewise, such situation is the result of haphazardly declared of Nepali municipalities recently from the government. Therefore, researcher, academicians, policy makers and urban planners show enthusiasm to be focused on urban study with well urban planning and development programs in future.

The process of urbanization is certainly related to development. The country can't develop as expected if it is mostly depend on subsistence agriculture. As defined earlier, urbanization concerns with the development of non-agriculture, commercial and industrial sectors. This makes clear that the country can be change through more urban areas in future, if most of nonagriculture sectors could be maintained properly. Therefore, urbanization is the synonym of modernization or industrialization directing to responsive change of the country.

\section{CONCLUSION}

Nepalese towns are categorized into different local levels as the analysis of China and USA (Xiaoyi, 1993; Southall, 1993) despite many gaps between developed and developing towns; however the authority has lacked clear plan and programs to study and implement them linking ruralurban visions as required in future. Theoretically, such types of concerns are embedded with urban anthropology wherein Nepal's efforts are very infant 
stage. As the view of Elinoff, Sur \& Yeoh (2017) based on interdisciplinary approach, we can also study the town in the context of construction especially focusing on construction materials, construction economy and construction politics of concerned towns or cities.

As discussed, the process of the modern development as industrialization of city and towns is recognized as urbanization, which is the one of the indicators of modern development. In urban areas, larger city as metro to middle and small towns are found. Such types of categories in Nepali context are known as metropolitan, sub-metropolitan, municipality and rural municipality in local levels. Recent restructure of local administrative levels indicates all local levels are recognized in different names as metro to municipality which is ultimately known as urban areas though most of the municipalities to rural municipalities are still based on agriculture. Despite the problem to define the town in Nepali context, we can say urbanization process in Nepal has been extending day to day i.e. 13 percent in 2001, 17 percent in 2011 (Devkota, 2012) and 27 percent (Subedi, 2014) though the figure is not so matched each other.

As the views of Seymour-Smith (1996), we can study the town focusing to comparative analysis of different castes and ethnicity in Nepali context with their original settlements, growing slums and squatter's areas (as shanty town) embedding migration and their socio cultural impacts in urban areas, rural -urban interface etc. In this sense, the study of Adhikari (2005) as Pradhan (2003) linking Pokhara with the peripheral rural areas and their interface can be next argument for the study of town in Nepal for the time to come. Therefore, it could be argued that theorizing towns in Nepali context is still complex by comparing even between cities and towns where our concerns should be focused on the relation between rural -urban settings and their reciprocal cooperation to be subsisted in particular areas.

At the beginning of urban recognition in the census of 1952/54, the growth rate in Nepal comparing to other countries was slow. Now it is speedily increased from 27 percent in 2014 to nearly 40 percent in 2017. From the development perspective, this is positive key indicator of development. At the same time, it is also urgent to maintain the quality of real urban characters, which is still challenging.

\section{REFERENCES}

Adhikari, J. (2005). The significance of town in rural development: A case study from Western Nepal. In P Onta et al (Eds.), SINHAS, 10 (2). Kathmandu: Mandala Book Point. 
Asian Development Bank. (2014). Report and recommendations of the President to the Board of Directors of ADB to TSTWSSSP, Nepal Project Number: 35173. Retrieved August 2014 from http://www.adb. org/countries/nepal/main

Bhandari, A. (2010). Urban anthropology: An overview of the discipline and scope. Himalayan Journal of Sociology and Anthropology IV. Pokhara: Deppartment of Sociology \& Anthropology, Tribhuvan University, Prithvi Narayan Campus. Retrieved from https:/www.nepjol.info/ index.php/HJSA/article/view/4664/3878

Courvisanos, J. \& Martin, J. (2017). Developing policy for Australia's small towns: From anthropology to sustainability. Retrieved from https:// www.researchgate.net/.../245908238_Developing_Policy_for_ Australia's_Small_

Devkota, K. (2012).Dynamics of urbanization in Nepal. Kathmandu: Alliance for Social Dialogue.

DUDBC, (1956). Planning norms and standards. Retrieved from https://www. dudbc.gov.np.

- - (2007). Declared small towns in Nepalese kingdom. Kathmandu: Government of Nepal.

- - (2010). Lists and profiles of small town in Nepal. Kathmandu: Government of Nepal.

Elinoff, E. Sur, M. \& Yeoh, B.S.A., (2017) Constructing Asia- An introduction. Retrieved Nov., 2017 from www.academia.edu/Documents/in/ Anthropology_of_Infrastructure Routledge

Ember, C. R, Ember, M \& Peregrine, P N. (2002). Anthropology. New Delhi: Pearson Education, Inc.

K.C, B.K. (1998). Trends, patterns and implication of rural-to- urban migration in Nepal. Kathmandu: CDoPS.

Mallick, U. C. (1981). Urbanization: Problems and political issues. In Gopal Bhargava (Ed.) Urban problems and policy perspectives (pp. 2-3). New Delhi. Abhinas Publication.

Marshall, G. (1994). Dictionary of sociology. New York: Oxford University Press.

MoFALD (2017) Gaupalika Ra Nagarpalikako Samkshipta Parichaya Pustika . Retrieved from https://www.mofald.gov.np.

Pandey, S. N \& Regmi, D. C. (2005) Nepalko Pragitihas (Prehistory of Nepal) Kathmandu: CNAS, TU.

Pradhan, P.K. (2003). Manual of rural linkage and rural development analysis. Kathmandu: New Hira Books Enterprises. 
Ray, A. (2017). Towns and cities of medieval India: A brief survey. London: Routledge. Retrived from https://www.amazon.in/Towns-citiesmedieval-India-survey/dp/1138234885.

Rua, M. M. \& Torres, A. (2016) Urban anthropology.Oxford Bibliographies Retrieved 23 Dec 2017 from https://www.oxfordbibliographies.com/ view/document/obo-9780199766567/obo...

Scupin, R, \& Decorse, C. (2012). Anthropology - A global perspective. Boston: Pearson

Seymour-Smith, C. (1986). McMillan dictionary of anthropology. London: Macmillan Press Ltd.

Sharma, P. (2003). The urbanization and development. Population monograph of Nepal. Kathmandu: CBS. Retrieved from cbs.gov.np/sectoral statistics/population/population_monograph_nepal_2003_all

Shrestha, B.K. (n.d) Town development fund's role in urban development of Nepal in the present change context. Retrieved from www.academia. edu/.../Town_Development_Fund_s_role_in_urban_development_ of_...

Shrestha, R.K. (1991). Chapter-2. Nepal: The society and its environment. In Andrea Matles Savana (Ed.) Nepal and Bhutan: Country Studies. Washington D C: Federal Research Division, Library of Congress. (3 $3^{\text {rd }}$ ed.). Retrieved https://archive.org/stream/nepalbhutancount00sava/ nepalbhutancount00sava_djvu.txt.

Southall, A. (1993). The introduction: Small towns and urbanization. In G. Guldin \& A. Southall (Eds.) in Urban Anthropology in China. The Netherlands: J E Brill. Retrieved from https://books.google.com.np/ books?isbn=9004096205

Subedi, B. P. (2014). Urbanization in Nepal. Population Monograph III. Kathmandu: CBS. Retrieved from cbs.gov.np/sectoral_statistics/ population/populationmonographnepa_2014

Thapa, K. (2016). Nagar vikas samiti kin ra kasari? (texts in Nepali). In A Bulletin of Sahari Vikas. DUDBC, 27 (16)13-15.

Xiaoyi, W. (1993). The Development of China's small towns. In G. Guldin \& A. Southall (Eds.) in Urban Anthropology in China. The Netherlands: J E Brill. Retrieved from https://books.google.com.np/ books?isbn=9004096205 